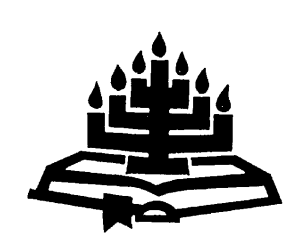

\title{
He is risen! A play based on Acts 1:1-12
}

\author{
R.G. Branch \\ School of Biblical Sciences \\ Potchefstroom Campus \\ North-West University \\ POTCHEFSTROOM \\ E-mail: rgbranch@crichton.edu
}

\begin{abstract}
He is risen! A play based on Acts 1:1-12

This play was written in response to a request to conduct a worship service 2 on Ascension Day, 21 May 2009, a Thursday, for primary school children, ages six to thirteen, from the Potchefstroom Christian School, an English-speaking school in Potchefstroom. 3 The worship service was part of an outreach of Potchefstroom North congregation, a member of the GKSA
\end{abstract}

1 You are welcome to present this play. Please let the author, Robin Gallaher Branch, henceforth referred to in this article as I, know you are doing it. Please give any proceeds to Potchefstroom North Church (GKSA) in Potchefstroom, South Africa, and stipulate that is is for evangelism purposes.

$2 \quad$ Worship is essentially a public, corporate, and dramatic event. Long (2001:43) defines it as follows: a service allows "the drama already present in worship to be brought to the surface and to be more deeply experienced" (italics - Long). This Acts play clearly makes use of the already present drama in Scripture. Von Balthasar (1988:25) adds the insight that drama illuminates Christian theology.

3 The elementary school child by nature is an explorer; a propensity toward adventure naturally readies a child to move on toward new horizons and accept new ways of doing things (Fritz, 1964:145). The Acts play offered children a chance to explore the meaning of their faith with their peers and to see the Scriptures presented in an interactive, noisy, exuberant way (Fritz, 1964:145).

According to Wheeler (1997: the inside of the front cover), characteristics of the audience, ages 6-13, are as follows: A six year old can understand the concepts of space, time, and the material world. Children ages 7-11 begin to develop an awareness of logical necessities; they can appreciate a symbolic knowledge that allows for generalisation. Children ages ten and up can form hypotheses, make assumptions, and draw conclusions. Furthermore, elementary school children are able to remember facts, know the sequence of events, and discover meaning in both (Stonehouse, 1998:162). 
(Gereformeerde Kerke in Suid-Afrika), to two local schools. ${ }^{4}$ An hour earlier on the same day, children from an Afrikaansspeaking school heard a sermon by Prof. Ben de Klerk. This article is dedicated to Professor De Klerk with thanks for his service to the Lord. Truly, his life exemplifies joy and honour.

The author of the play spent two and a half years (July 2002December 2004) with the Faculty of Theology at the North-West University in Potchefstroom - first on a Fulbright Fellowship and then as an Associate Professor with the Faculty of Theology for a finite term of 18 months. She was back for a visit doing research with her former colleagues when the invitation came to conduct the service for Potchefstroom Christian School on 21 May. 5 During announcements at a chapel service for theology students and faculty earlier in May, she asked for "six strong, broad, energetic, excited, and very handsome men" to be disciples in her new play for children. 6 Young men responded and rehearsals commenced.

$4 \quad$ The play was an appropriate resource for a worship service because it was a familiar resource and communicated in a way familiar to children. Children are familiar with television news. This effort at familiarity emphasises a chord in child evangelism: a child must feel he belongs; this "belongingness" will then lead a child into new areas of learning (Fritz, 1964:147).

5 Not all experiences in church are equally educative for all age groups of people in a congregation. In other words, a monologue sermon, the regular means of conveying the Biblical message in Protestant circles, may not work for all age groups all the time. There can be positive and negative aspects to public, corporate worship and drama (Brown, 2008:178). The Acts play attempted to create an experience for the children on which they could later fruitfully and creatively reflect (McNabb \& Mabry, 1990:51).

As I wrote the Acts play, I kept in mind insights and definitions that Quash (2005:3-4) gives: "Drama displays human actions and temporal events in specific contexts. Theodramatics concerns itself with human actions (people), temporal events (time), and their specific contexts (place) in relation to God's purpose" (italics - Quash).

6 Research shows that dramatisation helps a child to learn a story and get inside another person (Clark et al., 1986:544). Dramatisation, especially one in which a child participates, helps a child to understand his/her reactions to something and the reactions of other people, too (Clark et al., 1986:544).

McNabb and Mabry (1990:22) stress that the Bible is an understandable book for children; the job of a teacher is to present it as understandable and timeless. They add that Bible stories are open to interpretation and contain various levels of truth. "There is often more than one valid way of looking at a particular passage." (McNabb \& Mabry, 1990:23.) Drama offers one such way. 
The play was well received by the children. 7 it kept their attention because it was fast-moving and fun. 8 They learned a bit about the book of Acts and its opening story, the ascension, in a manner faithful to the Biblical text and yet one that creatively $\mathbf{9}$ incorporated contemporary elements. 10

Some teachers, however, hesitate to use drama. Reasons given are that it's a waste of time and control of a classroom may be in jeopardy. But Clark et al. $(1986: 545)$ say that those who refuse to use drama and plays in which a child participates as an actor or viewer display a lack of trust in their young charges and in themselves.

Over the centuries the Christian church has developed many different orders of worship. However, according to Long (2001:47-48) who stresses its public and liturgical aspects, any order can be considered a good avenue of worship if "worship is an acted-out story, a piece of community theater".

Perhaps a reason for the play's good reception and the fact that the children left smiling is because it was easily understood. Many children shyly shook my hand; their teachers hugged me as they said their thanks. One theology student in the audience sat crying because he said he saw how the play reached the children.

The positive feedback indicated the play's success. The play's dialogue is upbeat, short, and kept its audience - children - in mind. Similarly, Pulitzer Prize winner Frank McCourt decided to write his memoir, Angela's Ashes, like a child. "Children are almost deadly in their detachment from the world," he commented. "They tell the truth, and somehow that lodged in my subconscious when I started writing the book." (McCourt quoted in Grossman, 2009:21.) Similarly, this Acts play was written with a detachment from the text and with children in mind. It contains short sentences, active verbs, questions, exclamations, rowdiness, wonder, and a sense of live action.

In teaching children, it is important to stress that the Bible is not only a positive book but also a lot of fun (McNabb \& Mabry, 1990:21). McNabb and Mabry (1990:21) add that most kids see the Bible as a book of rules to keep them from having fun; but the Bible is not only Good Advice but also Good News!

Why is it fun? The Bible contains lots of adventure stories, many of them in the book of Acts. In the story that this play depicts, the disciples saw something amazing: Jesus whom they had seen die was now alive and was rising into heaven. They greeted these miracles with wonder and joy. Truly, the ascension of Jesus set them off on the adventure of their lives.

9 Creativity must have its place in Sunday School and in larger church settings. Creativity is a gift given by God to all in some measure, not just to a few. I believe it is a sin to neglect God's gift. A good working definition of creativity is that it combines something old with something new and the product is something different (Clark et al., 1986:545). Above all, creativity allows one to look at something old like the Biblical text with new eyes and present a wonderful, timeless truth in a new and appropriate way. 


\section{Opsomming}

\section{Hy het opgestaan! 'n Drama gebaseer op Handelinge 1:1-12}

Hierdie drama is geskryf as uitvoering van 'n versoek om 'n aanbiddingsdiens op Hemelvaartdag, 21 Mei 2009, 'n Donderdag, te hou vir laerskoolkinders tussen die ouderdomme van ses tot dertien jaar, van die Potchefstroom Christenskool - 'n Engelse skool in Potchefstroom. Die aanbiddingsdiens was deel van 'n uitreik van die Gereformeerde Kerk PotchefstroomNoord, 'n lid van die GKSA (Gereformeerde Kerke in SuidAfrika), na twee plaaslike skole. 'n Uur vantevore, op dieselfde dag, het kinders van 'n Afrikaanse skool na 'n diens deur prof. Ben de Klerk geluister. Hierdie artikel word met dankbaarheid aan prof. De Klerk opgedra vir sy diens aan God. Sy lewe getuig werklik van vreugde en eer.

Die outeur van hierdie drama het twee-en-'n-half jaar (Julie 2002-Desember 2004) by die Teologiese Fakulteit op die Potchefstroomkampus van die Noordwes-Universiteit deurgebring - aanvanklik met 'n Fulbrightbeurs en later as a gasprofessor van die Teologiese Fakulteit, vir 'n tydperk van agtien maande. Sy was op 'n navorsingsbesoek by haar vorige kollegas toe die uitnodiging gekom het om die diens vir die Potchefstroomse Christenskool op 21 Mei te hanteer. Tydens aankondigings by ' $n$ kapeldiens vir die teologiestudente en Fakulteit vroeër in Mei, het sy 'n versoek gerig vir "ses sterk, groot, energieke, opgewonde en baie aantreklike manne" om dissipels in haar nuwe drama vir kinders te wees.

Die drama is goed deur die kinders ontvang. Dit het deurgaans hulle aandag behou aangesien die verloop vinnig en prettig was. Hulle het iets oor die boek Handelinge en die openings-

10 The children and their teachers expected that a Christian message would be presented. Aldrich (1993:192) lists seven guidelines with subsets about gearing a message of evangelism to an unsaved person; some of his guidelines apply to a group and to children. I considered the following in writing the play:

1. What did I know of the children's background? I knew the children were black South Africans, English speakers, and that their teachers were primarily white women. The children arrived in an orderly way, and I complimented them on their good manners in my opening remarks.

2. What signs of openness to the gospel are seen? I knew the children knew Christian songs and would sing them as part of the service.

Anderson adds something that guided my writing and study. To be sure, the Bible is the record and the witness of events that climax the life, death and resurrection of Jesus Christ. To be a Christian, Anderson (2006:11) maintains, "is to understand one's existence in this dramatic context". 
verhaal geleer, asook oor die Hemelvaart - op 'n manier wat getrou aan die Bybelse teks is, maar tog kontemporêre elemente kreatief inkorporeer.

Text:

Acts 1:1-12; one of the disciples can read it to the audience before the play starts. ${ }^{11}$

Set:

A stage with a chair on stage left and a chair on stage right. If possible, have a PowerPoint slide of the Mount of Olives in the background.12 A website with a contemporary picture of the Mount of Olives like www.bibleplaces.com can be used.

Props: $\quad$ The disciples wear laminated nametags. So does the SABC EyeWitness News reporter. She carries a hand-held mike. The characters are in normal clothes, not in period dress. 13

Scene: The Mount of Olives.

Mannerisms: The disciples exude excitement and good will toward one another. Some rough-housing prevails. They are regular guys - and very excited about what they have seen. Two can come in and go out on piggyback, for example. All can move around and change positions on stage. The pace is fast and excited.

The disciples enter through the audience one way (from the Mount of Olives) and exit at the end of the

11 McCorkendale (2006:293) suggests the children's song "He brought me to his banqueting table" as a singing aid for a Sunday between Easter and Pentecost. It is suitable for Ascension Day. Sometimes the song is called "His banner over me is love". Verses include these:

He rose from the dead, and He is alive. Jesus went up into heaven. We are his hands, and we are his feet. He calls on us to love one another. He is the shepherd, and we are the sheep. He is the vine, and we are the branches. (McCorkendale, 2006:293.)

12 Von Balthasar (1988:259) asserts that theater is an illumination of existence, "and a central one at that". The stark setting of this play invited the children to fill in the blanks - the outside world of trees and rocks - with their imagination.

13 The Acts play is neither an allegory nor a typology. But it does seek to integrate contemporary experience - a news format - into patterns inherent in the Biblical text and into a pericope that lends itself to enactment (O'Keefe \& Reno 2005:73); for an excellent explanation of typology and allegory, cf. O'Keefe \& Reno (2005:69-113). 
play also through another part of the audience (on the way to Jerusalem).

A possibility for staging is to think in groups of threes: Matthew/Thomas/John and Peter/James/Andrew, for example.

Time: $\quad$ AD 30, 40 days after the crucifixion of Jesus; 40 days after Passover; 10 days before Pentecost.

Characters: SABC EyeWitness News reporter - pretty, professional, not a believer.

Disciples: Matthew, a tax collector

Peter, a fisherman

James, a fisherman

Andrew, the brother of Peter, a fisherman

Thomas

John, a fisherman, the brother of James ${ }^{14}$

Introduction: (The woman who plays the SABC reporter. A suggestion is that she dress in a black turtleneck and black trousers. She does not yet wear her nametag. $)^{15}$

The story you just heard is contained in the book of Acts. ${ }^{16}$ In a few minutes you will see a play based on this story. ${ }^{17}$ But first l'd like to

14 McNabb and Mabry (1990:25-27) offer these tips on how to approach a Bible study with children:

- $\quad$ Find the passage's main point.

- Consider the passage's context.

- Use the canonical principle of letting Scripture interpret Scripture.

- Look at how to apply the passage to one's life.

15 I assumed that the children did not know the stories in Acts, for on the whole, people are largely ignorant of the stories in the Bible (Hunter, 1992:55). I wanted to put everybody in the audience on the same footing and knowledge level.

16 There are two ascension stories (Acts 1:1-12 and Luke 24:36-53, specifically verses 50-53). This play concentrates on the Acts narrative. Wilson (2007:49) maintains the ascension stories are one and the same and must be read together. I agree.

17 Vanhoozer (2005:79-80) sees three benefits to "knowing God theatrically." 
give you a bit of information about the book of Acts. Traditionally, its author is Luke. He wrote a kind of history that reads like an adventure story. He wrote to a man named Theophilus. Theophilus was his patron. That meant that Theophilus paid Luke's expenses as Luke traveled around getting accurate information. Probably Theophilus was a wealthy Greek who had a lot of knowledge about the Roman world.18

The book of Acts is theological history. 19 Theological history means that the book contains stories about real people and the ways God directs their lives. The writer, Luke, was a physician, a doctor. He was a Gentile, not a Jew. The Jews were the people to whom God gave his law. Luke is probably the only gentile writer in the Biblical text. He also wrote the Gospel of Luke. So it is natural to read the two books, Luke and Acts, together.

Scholars think the book of Acts was written for many reasons including the following:20

- Theo-drama reinvigorates what Vanhoozer terms "our anemic imaginations, diluted as they are by the mess of pottage we are fed by contemporary culture."

- A theatrical metaphor enables people (the actors, the writer, the congregation/audience) to see their ordinary and daily lives as replete with urgency, vibrancy, tension, and importance. The ordinariness of daily life is a window for God's intervention.

- Vanhoozer sees the metaphor of theatrical direction as enriching both Biblical authority and theology by providing "a complex yet concrete model for conceiving the relationship between text and interpretation". This concrete model is performance, he says (italics - Vanhoozer).

Wall, 2002:8.

19 Neil, 1973:25. Quash (2005:1) stresses the value of what he calls a "'theodramatic' conception of history"; he defines this as "a way of thinking theologically about (the) historical process and the historical character of human agents and environments that emphasises their dramatic features".

20 Wall (2002:8-10) concludes his list of reasons with these two: Acts, because of its stories, deepens the faith of new believers or people thinking about converting like Theophilus - and maybe like you! A person is born a Jew or a Gentile, an American or a South African. One becomes a Christian.

Acts, like many of the books in the Bible, was written in response to crises. One crisis the book of Acts addresses is the newcomers, the Gentiles. Acts welcomes the newcomers, the Gentiles, equally with those Jews who also believe in Jesus. 
- Acts was written to bring together different faith communities and to show them their common heritage of belief in Jesus.

- Acts takes a strong stand against idolatry. Idolatry is the worship of idols and was prevalent throughout the Roman world.

- Acts defends Christianity. The big word in Latin for defense is apologia. Acts defends the claims of Jesus and establishes a new religion.

- Acts shows many missionary endeavors and journeys. It establishes a focus of the church: missions. Missionary work is telling somebody about the love of Jesus and how to become his follower.

The author, Luke, has a talent for writing about people who seem ordinary or insignificant and showing how interesting they are. The book of Acts takes readers all over the known Roman world. There's a lot of adventure in Acts: stories about a shipwreck and someone who is bitten by a viper and lives; stories about a crippled man healed and a dead woman brought back to life.21 The book is really amazing and unforgettable.22 It talks about ordinary people who live extraordinary lives as people of faith and believers in Jesus. ${ }^{23}$

Let's look at the themes of the book of Acts in another way. 24 First, the book of Acts is the story of Christian beginnings. Second, it shows that the good news of being loved by Jesus and saved from hell by him is for both the Jews and for those who are not Jews, the Gentiles. The book of Acts talks a lot about right and wrong ways to live. 25 Third, it reaffirms that Jesus will come again and gives people

21 Acts $3 ; 9: 36-43 ; 27: 27-44 ; 28: 1-10$.

22 Cf. Marshall (1989:17).

23 A child's active imagination is a great tool and strength to work with for a teacher intent on training a child in the faith (Stonehouse, 1998:158).

24 The Acts play was designed to be fun, but it also was academic, not devotional; it encouraged the awareness of a formative event in Christian history; it exposed the students to a different view of the text, an eyewitness account; it sought to educate the children about the Ascension as recorded in Acts in a way that combined scholarship and fun (cf. Ratcliff, 1992:129-130).

25 I was mindful of a couple of Spurgeon's rules for teachers of children: I must be taught by God myself before I can teach; I must ask God to use me as a teacher; and I must respect my audience (Spurgeon, s.a.:92, 93). First and foremost, children must be taught morality, he (Spurgeon, s.a.:87) adds. 
assignments, work to do, until He does come again. Fourth, it affirms that God is still at work in his world and has good purposes for his world. 26

\author{
Now I want you to put on your "imagination hats."27 I am putting on \\ mine. 28
}

(She pretends to put on a hat, as do the people in the audience.) ${ }^{29}$

Furthermore, children are socialised within or without faith, and exposure to faith is a requirement for acceptance of belief, but how socialisation into faith takes place can make the difference between acceptance or rejection of it (Ratcliff, 1992:119). Passing on the faith is a requirement for covenant believers and a crucial concern for religious education (Ratcliff, 1992:119). The tripod for passing on the faith is the family, school and community.

26 Marshall, 1989:19, 20, 23.

27 Young children are dramatic and playful by nature, spending hours acting out the events their imaginations create (Stonehouse, 1998:156). Children express a love of the dramatic, are comfortable with mystery, and desire to explore and investigate things themselves; that is how they learn (Stonehouse, 1998:156).

The use of the medium of a play for Ascension Day recognised that an unusual presentation of a text can deepen a child's engagement with the Bible (Brown, 2008:184).

28 What I call "imagination hats," Berryman (1995:37) calls "the wondering" ability. He notes that children, already so good at "wondering", must be guided and supported by the storyteller. I was very conscious of that as I wrote the play and as I portrayed the SABC news reporter. I hoped to catch the wonder of the Biblical text passage via the excitement of the disciples and their truthfulness. The disciples were role models these children could trust and emulate. My young audience participated avidly, because by nature children pretend and wonder easily; they do not have to be taught how to imagine (Clark et al., 1986:543).

Berryman (1995:38) makes a teacher accountable by saying it is the teacher's responsibility in a group's wondering

... to genuinely enter the lesson himself or herself. The unspoken part of the lesson is the authentic participation of the teacher, who is moving toward discoveries appropriate to himself or herself. There is no talking down to children as they wonder, or boiling down of Scripture's profound depths to a thin 'kiddy religion'.

Correctly done, a successful lesson for children "makes them joyful" and gives the children "something they deeply need ... This is not the elation that entertainment might give. It is the happiness that the satisfaction of the soul's wholeness can give." (Berryman, 1995:38.)

29 Imagination, is at work in the forming of faith. Stonehouse (1998:154) writes: "As children stretch to understand God's involvement in their experiences and in 
We are going back to the year AD 30. That is 1980 years ago! A long time ago! You are going to participate as the audience in a play. ${ }^{30}$ We're going to a place called Judea; sometimes it is called Israel. It is an occupied nation. That means the people, the Jews, are conquered by the Romans. Roman soldiers are everywhere and the people have to pay a lot of tax to Rome. Most do not like it, because Rome is not popular at all! Almost all the Mediterranean world has been conquered by Rome. The king of Rome is called the Caesar. He is the most powerful person in the world.

Right now we are on the Mount of Olives, a big hill about threequarters of a mile outside of Jerusalem. 31 Forty days ago the Romans executed three men they called criminals. Two were

their world, they call on their imagination to provide explanations or answers for questions they had never thought about before. Often their explanations are magical."

30 My hope in writing the play was that the play would help the audience to find meaning in the passage (cf. Hunter, 1992:57). A film, video, or play shows teacher planning and a contemporary way of communicating the Christian faith in a way that will continue to live in the minds of students (cf. McNabb \& Mabry, 1990:52).

Vanhoozer (2005:37) writes that his book "insists that God and humanity are alternately actor and audience". He sees life as divine and human interactive theater. He (Vanhoozer, 2005:37-38) maintains that "theology involves both what God has said and done for the world and what we must say and do in grateful response". The disciples in this play clearly act in a joyful and grateful way to the commands of the risen, alive, and ascending Jesus.

31 Marshall, 1989:62. Drama has several advantages including the following (cf. Clark et al., 1986:545-546):

- Enacting a story makes it more real.

- A drama may show honest feelings that one may skim over when reading the text.

- Interactions within a drama promote new friendships and let a teacher and students get to know each other in new ways.

- Ideas and feelings expressed become part of the actor.

- Enacting a story helps an actor to think outside him-/herself.

- Enacting a story gives the actor, via imagination, insights into another person's thinking and actions.

Just as Christ says he can be encountered in many ways - as the poor, the naked, the one in prison, and the hungry (Matt. 25:31-40) - so the Biblical text can be encountered in many guises (Stevenson-Moessner, 2008:22). The pericope of Acts 1:1-12 can be treated in a conventional way as a straight sermon or, as I did, presented as a play. 
robbers. 32 One was Jesus of Nazareth, a man known to everybody in Jerusalem and the surrounding area for three years for his good teaching and his many miracles. He healed many people and fed thousands. ${ }^{33}$ His disciples and those who loved Him did not think of Him as a criminal, but He died, charged with treason. He said He was a king, but He said his kingdom was not of this world. ${ }^{34}$ What could that mean?

Remember, the execution was 40 days ago. He died and was buried. 35 But today, here on the Mount of Olives, his disciples are saying they have seen him! But that was not all, they are also saying that they watched him go up in the sky! Let's find out what they're saying. ${ }^{36}$

\section{(She puts on her nametag, SABC Reporter.)}

I am now a reporter for SABC and this is EyeWitness News!37 You are the TV audience. This is breaking news! $\mathbf{3 8}$

Mark 15:27; John 19:16-18.

Luke 5:12-16; 8:40-56; 9:10-17.

$34 \quad$ Luke 23:1-3; John 18:28-37.

35 Luke 23:44-56.

36 Because of the character of the SABC news reporter who was not a believer, knew nothing about the new movement, and was "professionally neutral" in her questions, there was no possibility that the audience would feel lectured or demeaned (cf. Hunter, 1992:61).

37 SABC stands for the South African Broadcasting Corporation. If the play is performed elsewhere, use the television network most familiar to a young audience.

38 Why a play? Drama conveys ideas, values, beliefs, and attitudes and provokes us as readers, hearers, and viewers to analyse what is portrayed on stage (DiYanni, 2008:901). A play is meant to be experienced both intellectually and emotionally (DiYanni, 2008:901).

Drama is a staged art; in this it is unique (DiYanni, 2008:899). The purpose of writing a play is to have it performed successively in front of audience after audience. A play may be a vehicle for persuasion (DiYanni, 2008:899). In other words, it may have an agenda. Shakespeare, Ibsen, Elliott, Shaw, Sondheim, Miller, and Bernstein each, arguably, had issues to present, ideas to propagate, and views to pummel into an audience. 
(The disciples enter boisterously. ${ }^{39}$ They wave and say hello. They wear nametags. They interact excitedly 40 with the audience as they enter. ${ }^{41}$ A feeling of good will prevails. ${ }^{42}$ )

Reporter: I am here on the Mount of Olives with Matthew, Peter, Andrew, James, John, and Thomas. Hello, gentlemen. We can see Jerusalem in the distance. 43

39 I wanted to teach and bless those whom Spurgeon (s.a.:5) calls "young in grace." I saw the invitation to present the service on Ascension day as a way to do that by using a medium the children knew, television, in a positive way. The actors in the play were a special blessing to me. Spurgeon (s.a.:10) characterises those who work with children this way: "If you want big-souled, large-hearted men or women, look for them among those who are much engaged among the young, bearing with their follies, sympathizing with their weaknesses for Jesus' sake." The seven volunteers who worked so hard on the play - Godwin Mushayabasa, Nikolaas Pienaar, Danie Potgieter, Johann Engelbrecht, Carlo Wright, Gideon Semakuezi, and Albert Coetsee - truly are that!

40 The actors were instructed to keep the action moving; avoid a monotone voice; speak clearly; smile often; avoid "walking" on another's line; allow for pauses, wonder, and laughter; and avoid sounding pompous or know-it-all (cf. Childers 1998:93-95). I was impressed with the unselfishness of those I came to call "my disciples". The actors were what Childers (1998:95) calls unselfish performers. Consequently, the resulting performance of the Acts play was "full of the voice and life of the text" and "full of the voice and personality" of each actor (Childers, 1998:95).

41 Stevenson-Moessner (2008:20) defines exegesis as "to lead out" or "to interpret." She (Stevenson-Moessner, 2008:20) observes that this definition evokes an image of leading from one location to another, "as from experience to text or from text to experience". The play's actors and the play's audience were about to experience the retelling of eyewitness accounts of the ascension of Jesus.

Anderson (2006:15) seems to be smiling when he writes "the Great Dramatist is apt to lure us from the spectator's balcony and put us into the act". The purposeful action of putting on "imagination hats" brought the audience into the drama in a non-threatening and gracious way.

42 When a play is performed, one is first struck by its representational quality. Drama is mimetic art - art that imitates and reflects life, emotions, and experiences (DiYanni, 2008:900).

43 Dialogue in a play functions on two levels: first, what the words mean and second what they reveal and suggest about the characters' behavior, backgrounds, feelings, ethics, motivations (DiYanni, 2008:901). Drama entertains and "offers provocative ideas about the life it portrays, and it provides an imaginative extension of its possibilities" (DiYanni, 2008:901). 
Reporter: Matthew, will you start telling our viewers what happened, please? You other disciples can say things as well.44 I know you have something amazing to say! 45

Matthew: Jesus was killed 40 days ago. He was crucified on a cross on the execution hill outside Jerusalem called Golgotha. 46

Andrew: Then He was buried in the tomb of a rich man, Joseph of Arimathea. Roman guards guarded it. 47

John: He suffered greatly. He died. But there was a resurrection! 48 He left the tomb! He's alive! He rose from the dead!49 We've seen Him on and off for 40 days.

Peter: $\quad$ The tomb cannot contain him! The Roman guards could not stop him!50 We saw him today go up into heaven. 51

44 In the Acts play, the children saw the disciples express their faith and its progressions. As such, the Acts play sought to create an environment where children could investigate the ideas and images they are forming about God (cf. Stonehouse, 1998:159). Indeed, stories are at the heart of faith development for children, because stories capture and communicate theology for them (Stonehouse, 1998:161). In their elementary school years, children start taking ownership of the stories, beliefs, and religious rituals esteemed by those in the faith community to which they belong (Stonehouse, 1998:162).

45 The play emphasised the memorisation of lines. This was teaching by example on a subliminal level. Fritz (1964:149) stresses the importance of memorisation for children, stating that "words once understood become a part of the stuff of which concepts are formed and may be a strong influence in the child's later choices and decisions as well as his conduct".

46 Matthew 27:33. From here on in the play, only Scripture references that are not part of Acts 1:1-12 are mentioned.

$47 \quad$ Matthew 27:57-66.

48 The resurrection can be seen as one of the many interventions of an active God breaking into time (Von Balthasar 1988:26).

49 Matthew 28:1-10; Mark 16:108; Luke 24:1-10.

50 The pattern of the church fathers was to interpret the ascension as the climax of the resurrection (Kapic \& Van der Lugt, 2007:26).

51 The phrase "into heaven" occurs four times in Acts 1:10-11 (Maile, 1986:55). Fuller (1994:392) notes that the disciples were not looking "toward heaven" but 
James: Since his resurrection, He has eaten with us many times and performed many signs for us, too.52 Today he disappeared into a cloud!53

Thomas: Yes, we have seen Him again and again! $54 \mathrm{He}$ is Lord and God! He has a body, but it is different from our bodies. Jesus can appear and disappear as $\mathrm{He}$ wishes. 55

Matthew: Jesus spent the days after his Crucifixion and Resurrection teaching us that his suffering, death, and Resurrection were in accordance with our Scriptures. $\mathbf{5 6}$

Together, his life, death, and Resurrection, constitute God's mightiest act for the salvation of the world. 57

John: You know, on a human level, it was so interesting to see Jesus just be a regular guy and eat with us. $\mathbf{5 8}$

Reporter: My goodness! You men are so excited! You've seen a lot! James, tell me and our viewing audience more, please. 59

actually were looking "into heaven"; Acts 1:11 says they actually saw Jesus go into heaven.

52 John 21:1-14.

53 Clouds are associated with God's presence: Exodus 13:21; Psalm 68:4, 33; 104:3 (cf. Wilson, 2007:49).

54 During the 40-day period between the Resurrection and the Ascension, there are numerous comings and goings of the Lord (Grant, 2007:39).

55 Anyone associated with young children knows they love stories (Stonehouse, 1998:156). They especially like stories which strongly state good and evil and in which the good prevails (Stonehouse, 1998:157). In the Acts play, good prevails: the crucified and dead Jesus comes back from death, is alive, and as alive rises into the air!

56 In Acts 1:3, Luke relates that Jesus showed Himself alive to the apostles, "after his passion, by many infallible proofs, being seen of them forty days, and speaking of the things pertaining to the kingdom of God". The infallible proofs seem to mean interviews and communications with people (Robinson, 1993:31).

$57 \quad$ Neil, 1973:64.

58 Cf. Neil (1973:65); Luke 24:43; possibly Acts 1:4.

59 While it is possible that some in the audience identified with the SABC news reporter as a seeker or as someone who didn't know anything about 
James: Jesus spoke to us about the kingdom of God. The kingdom of God is God's good rule on earth.

Reporter: When will that happen?60

James: It has started already - with Jesus! Jesus has been instructing us about the kingdom of God. This was always central to Jesus' preaching and ministry. ${ }^{61}$

Thomas: We're a continuation of what Jesus began. Our work as witnesses will continue the work of Jesus.

John: We want to tell everybody all that Jesus did and taught from the beginning to the end!

Matthew: Throughout these 40 days, Jesus kept on showing Himself to us. He kept appearing in our midst when we were gathered together. By this He gave us many, many proofs that $\mathrm{He}$ is alive!

John: Death cannot keep Him! It seems that He came the most often to us when we were praying.

Andrew: Yes, prayer seems to draw Jesus. Jesus loved to pray. And He made prayer fun!

James: Let me explain why prayer became fun. We asked Jesus to teach us how to pray. He taught us to talk to the Father, the One who loves us the best. 62

Peter: That's right. He taught us to say, "Our Father in heaven, hallowed by your name. Your kingdom come, your will be done on earth as it is in heaven". 63

Christianity, others may have identified with one of the disciples. Each disciple portrayed himself as someone with dignity and a responsibility to share the good news of Jesus with others (Hunter, 1992:62).

60 I attempted in the writing of the play to address questions the children might have; for example, the SABC reporter asked a lot of questions (cf. Hunter, 1992:59). Furthermore, a benefit of the play was that the children were exposed to six great guys as role models, what Hunter (1992:59) calls credible Christians - students in the Faculty of Theology at North-West University.

Wall, 2002:41. 
Reporter: That is a beautiful prayer! You must have been praying a lot in these 40 days. John, tell us more!

John: Yes, we thought Jesus would be dead forever. At first we thought that everything was lost. We wept.64 We did not realise that the work of God in Jesus goes on! Yes! We have seen the risen Jesus! 65 We were so surprised to realise that the work of God continues. 66

Andrew: We are waiting for something definite 67 - the coming of the Holy Spirit. Right now we don't know what that means. But we're excited! Jesus promised us the Holy Spirit, and Jesus always keeps his promises.

Peter: It's a promise! Right! We don't know what it means to be visited by power on high! We're curious! 68

Thomas: He gave us some commands.

Reporter: Commands? What did Jesus command, James?

James: He told us not to leave Jerusalem. He told us to wait for the gift the Father had promised.

Matthew: We believe Jesus meant the gift will be the Holy Spirit. Then Jesus also reminded us that John the Baptist, his

63 Matthew 6:9-10. What is commonly known as the Lord's Prayer continues through verse 14 .

64 John 20:15.

65 There are six reasons the Ascension is important (Maile, 1986:56-58):

- It is the confirmation of the exaltation of Christ in His present Lordship.

- The Ascension is the explanation of the continuation of the ministry of Jesus and the church.

- It is the culmination of the resurrection appearances.

- The Ascension is the prelude for the sending of the Holy Spirit.

- It is the foundation of the Christian mission.

- The Ascension is the pledge of the return of Christ.

66 Spence and Exell, 1950:12.

67 Spence and Exell, 1950:12.

68 Spence and Exell, 1950:13. 
cousin, baptised with water. But soon in a few days we would be baptised with the Holy Spirit. 69

Reporter: What does that mean?

All: $\quad$ We don't know!

Thomas: But we know it will be good because it comes from Jesus!

Reporter: How will you wait, Andrew?

Andrew: We'll wait together! Everybody will be together! We love each other so much that we cannot be separated!70 There are about 120 of us - the disciples, the women, and Mary the mother of Jesus. ${ }^{71}$

Thomas: We will wait praising and praying and thanking God! We will be very active while we wait! The living Jesus shows us the Father's love!

James: We have come through such sorrow, and now we are rejoicing! Jesus is alive! The kingdom of God is here! Jesus is alive! We want the whole world to know the joy we have! 72

Reporter: What is the Holy Spirit? I'm confused, Peter.

Peter: We don't know much about the Holy Spirit. But we're going to find out! I have a feeling the Holy Spirit will dominate our lives and the way we tell the story of Jesus. 73

Reporter: Please tell our audience more! What happened?

Matthew: Well, we did ask Him a rather stupid question.

69 The intent of the baptism of the Holy Spirit is the empowerment of the mission of the church (Weissenbuehler, 1992:62).

70 The teaching of Jesus is strongly relational (Grant, 2007:40).

71 Acts 1:13-15.

72 The disciples do not react with a sense of extreme loss; they experience joy (Shore, 2007:21).

73 Cf. Neil (1973:64). 
Reporter: Matthew, you sound a bit embarrassed. What was it?

Matthew: We asked Him when He would restore the prominence of Israel in the world and the kingdom of Israel.

James: Yes, Jesus rebuked us, but in a nice way. He is always to the point and gracious. He basically said it was none of our business!

Thomas: We cherish dreams about the glory of our country Israel. We want Israel be restored. We want the God of Israel to be worshiped all over the world. But Jesus told us that we were not to know when these things would happen. That's part of waiting. But while we wait, He has given us assignments.

Reporter: How can Israel be restored? After all, Rome is in control and Caesar rules the world. There are Roman soldiers all over the city of Jerusalem. Any rebellion will be met with death. You know that, John.

John: Jesus said it was not for us to know the times and the seasons. I think He meant we were not to expect to see immediately what God's total purpose is. $\mathbf{7 4}$ Maybe we can't handle all the knowledge!

Andrew: The amazing thing is that whenever Jesus gives a rebuke, He gives a new assignment. This new assignment is to work for the kingdom of God on earth. 75

Thomas: Minding your own business turns out to be doing what God tells you to do and letting God do his part!

Reporter: This is all so exciting! A dead criminal coming back to life! Tell our viewers more about the kingdom of God! What was Jesus' command, John?

John: He gave us the assignment to wait. He told us to wait in Jerusalem until we receive power!

74 Acts 1:7 in essence says this: It is God's business and not yours. The disciples are correct, however, in thinking that the restoration of all things does include the restoration of Israel (Weissenbuehler, 1992:63).

75 Neil, 1973:66. 
Andrew: You see, we had wanted Israel to be restored to its former glory and to shake off the shackles of Rome. The prophets have decreed the return of the glory of Israel.

Peter: $\quad$ But I guess it will happen later. God probably has something bigger and greater in store.

Andrew: And we're a part of it!

Thomas: We can expect God to surprise us! He is full of big surprises! He delights in doing the unexpected. 76

James: $\quad$ The amazing thing is that what God began continues! 77 With us and it keeps continuing! 78

Andrew: We're about to tell the story of our friend, God's servant Jesus, to the world!79 But first we must obey his command to wait in Jerusalem.

Reporter: I can see you are excited. You look like men who are telling the truth. Keep talking! Tell our viewers what happened, Andrew.

Andrew: He told us to wait in Jerusalem. The Holy Spirit will come upon us.

James: We will receive power. We will be his witnesses.

John: We will be his witnesses first in Jerusalem, then in all Judea, then in Samaria, and then to the very ends of the earth. 80

Peter: $\quad$ Then while Jesus was talking to us, He started to rise in the air.

76 Cf. Spence and Exell (1950:13).

77 The drama portrayed here in Acts 1:1-12 and indeed throughout the entire Bible is always at God's initiative (Von Balthasar, 1990:53).

$78 \quad$ Neil, 1973:63.

$79 \quad$ Neil, 1973:25.

80 The important direction in the ascension story is not up but out (Shore, 2007:21). 
Reporter: Rising in the air! That's amazing! You mean straight up, Peter?

Peter: $\quad$ Yes. He kept on going. And we kept on watching him. $\mathbf{8 1}$

Reporter: How did you feel?

Matthew: We felt a lot of things - fear, awe, confusion. We'd never seen anybody go up into the sky before and disappear into the clouds. I felt some grief, too. I felt as if my best friend were leaving me.

Reporter: What does the cloud mean, Thomas?

Thomas: In our Scriptures, God is often in a cloud. He uses it as a covering. 82

Reporter: There were reports you also saw an angel. What was he like?

Thomas: Suddenly two men appeared. Yes. Two. They were in white. 83

Reporter: What does that mean - that they were dressed in white, James?

James: It is a traditional way to refer to an angel as someone in white. 84 We believe they were angels.

Matthew: Yes, two angels, dressed in white. Angels bring messages from God. Actually, angels are quite common in our Scriptures. 85

John: But it's always rather a shock to see them!

81 While Jesus is in heaven, He passes beyond our realm of vision, but this does not reduce our assurance in his existence (Fuller, 1994:392).

82 Using Psalm 68 as a cross reference for the Ascension, Charles (2008:15-16) notes that the Rider of the clouds becomes the Climber of the cross and the Ascender into the clouds.

83 The two men in white underscore the connection between the Resurrection and the Ascension (Weissenbuehler, 1992:64).

$84 \quad$ NIV Study Bible, 1995:1647n.

85 Cf. Genesis 16:7; 22:11; 2 Samuel 24:16; 1 Kings 19:7; 2 Kings 19:35. 
Reporter: Andrew, have you disciples seen angels before?

Andrew: Yes, women in our fellowship saw two angels three days after Jesus' death. We didn't believe them. 86 Now that we've seen them, too, we believe the women.

Reporter: I'm glad you believe the women! What happened next?

Thomas: $\quad$ There we were, looking up and watching Him go up into heaven. We couldn't say anything. It was all so amazing.

Reporter: John, did the men in white say anything?

John: $\quad$ Yes. Again we sort of got rebuked. It's as if we weren't getting it - as if we were not understanding anything. They asked us why we were looking up. 87

Andrew: We told them we were watching Jesus.

James: $\quad$ They seemed to want us not to waste any time. They told us this Jesus would return in exactly the same way - only coming down.

Thomas: And we were to do what He told us all to do. So we are going back to Jerusalem rejoicing. We are jumping all over each other with joy. Praising God! We're stopping people on the way and blessing them. We cannot contain our joy - so we have to share it.

Reporter: Maybe I am the one not getting it, not understanding it. This is all very amazing to me. Perhaps it is the same to our listeners. Can you describe it one more time, please? Peter, let's start with you.

Peter: $\quad$ Certainly. Jesus was lifted up into the sky. He departed from us. He was taken away into a cloud. 88 Right be-

86 Luke 24:1-12

87 The angels' question points to the obvious, Wilson (2007:51) says, "You have your orders! Get on with them!"

88 The Ascension means these four things, according to Weissenbuehler (1992:65):

- Jesus now continues his mission in the world through the apostolic witness of believers. 
fore our eyes it happened! The cloud was the heavenly glory of God. 89

Thomas: The Ascension of Jesus is a guarantee that He will descend again, that $\mathrm{He}$ will come again. 90

Andrew: Right! If He can go up, He can come down!91

James: Let us say right now that Jesus is the risen Messiah! He is the Christ, the Anointed one, the Chosen son of the living God. We just saw He went straight up to heaven. He has taken his place at the right hand of God. He is exalted as Lord and King. ${ }^{92}$

Thomas: This is the beginning! Our command is to start in Jerusalem, Judea, then go to Samaria, then to the uttermost ends of the earth.

Peter: It will mean a lot of travelling!

- In changing places, so to speak, Jesus exercises lordship over the church in the Spirit.

- $\quad$ The Ascension presupposes the coming of the Holy Spirit.

- The Ascension bears witness to the inevitability of the return of Jesus to complete what is now being accomplished.

Wilson (2007:50) adds this important point: the Ascension establishes the whereabouts of Jesus: Jesus is in heaven.

89 Marshall, 1989:61.

$90 \quad$ Marshall, 1989:61.

91 The Ascension is not the last word: He will come again (Wilson, 2007:51; cf. Ps. 68:18).

92 Neil, 1973:66. Effective evangelism takes place over a time span. The Good News includes the love of God, the grace of God, the Kingdom of God, forgiveness of sins, new birth, reconciliation, sanctification, justification, and holiness (Hunter, 1992:103). The play included mention of many of these concepts. They were defined as the play progressed by the characters' actions and words.

Effective communication involves telling stories, especially the kind of stories that enable people to discover the point for themselves (Hunter, 1992:105). Effective Christian communication may involve word plays, proverbs, and drama (Hunter, 1992:104); these tools stick in one's memory bank. 
John: And adventure! We're so amazed and excited about being part of it!

Matthew: Oh, how will we pay for it?

James: We don't know! But we'll trust and pray and do the task at hand.

Peter: $\quad$ Yes, Jesus has left in body! But He is here in our hearts right now. In each heart!93

Reporter: In your heart? That's amazing! How do you know that $\mathrm{He}$ is in your heart, John?

John: How do we know it? Look at our eyes! He's there!

Reporter: I don't understand. There's so much mystery to all this.

John: That's right. There is mystery. ${ }^{94}$ But we know enough of God's character to trust Him. 95 We disciples certainly know Jesus, and we trust Him entirely.

Matthew: The amazing thing is we saw Jesus go up, but I feel Him here with me right now. His resurrected body and his spirit mean that He can be present in heaven and here with us on earth. 96

Reporter: Throughout this interview, I've noticed your joy, and I'm sure our viewers have, too. 97 Can you say in a sentence why you're so joyful?

93 Jesus now intercedes for us in heaven, but the Holy Spirit intercedes for us in our hearts here on earth (Rom. 8:26; McGowan, 2007:52-53). The play follows Spurgeon's (s.a.:90) dictum about teaching children: teach children the absolute necessity of a change of heart.

94 Cf. Deuteronomy 29:29.

95 God describes Himself in Exodus 34:6-7. The play communicates what Spurgeon (s.a.:91) cites as a necessity of child evangelism: teaching children the joy and blessedness of becoming and being Christians.

$96 \quad$ Neil, 1973:67.

97 Children learn their behavior from others (Ratcliff, 1992:119). The Acts play intended to show that accepted behavior is excitement about the good news of Jesus; furthermore, excited people convey this message: Jesus is alive, is risen, and will come again! 
Matthew: Because He lives!

Thomas: Because He rose from the dead! We saw Him ascend into heaven!98

John: Because He's coming back!99

Peter: Because He loves me and the whole world!

Andrew: Because He gave us a job to do!100

Thomas: Because we're part of God's plan!101

Reporter: All of that is good news! Can you describe this Jesus? Let's start again with you, Matthew.

Matthew: He called himself the Good Shepherd.102

Thomas: The bread of life. 103 The light of the world.104

98 In the account of Luke 24:50-53, Jesus departs and blesses his disciples at the same time. Kapic (2005:252) calls this "a profound portrait of the ascending Christ". The disciples now know Jesus as the One who not only promised peace but is Peace. As High Priest, Jesus not only pronounced a benediction over his disciples in the Luke account, but also became the benediction. Kapic (2005:252) concludes his observations with this astonishing theological statement: "Those who saw the ascension witnessed the personification of Aaron's benediction in Jesus Christ" (italics - RGB; cf. Num. 6:24-26).

99 Revelations 1:8; 22:12-13.

100 Shore (2007:21), writing in contemporary language, notes that the "ascension is not a picture of a risen Christ who leaves the disciples and goes into retirement (as if the Son sinks down into a throne at the right hand of the Father and says, 'Whew, am I glad that job is done'). Instead, the ascension gives us a picture of Jesus as an advance worker for his own followers."

Darden (2006:13) agrees with the disciples' exuberance. Writing to those wishing to communicate the Good News, he says: "Here's the wonderful thing we are part of that story! We play an important role in God's Great Plan. This is our story! The Bible is our roadmap and our cast list. Knowing how these stories are used, how they're important, and what to watch for is important so we will know our parts in this great cosmic comedy/drama" (italics - RGB).

101 Jeremiah 29:11-13. A purpose of the play was to show children that the church, the body of believers, is a powerful force in the world, from the Mount of Olives onwards (Fritz, 1964:145).

John 10:14.

103 John 6:35. 
John: The gate the sheep must enter.105

James: The resurrection and the life. 106

Peter: The way, the truth, and the life.107

Andrew: He said $\mathrm{He}$ is the true vine.108 $\mathrm{He}$ told us to follow Him. 109

Matthew: We must continue telling the world what God has done and is doing through his servant Jesus. ${ }^{110}$

John: We have the message of salvation in Jesus to proclaim and mighty works to perform in Jesus' Name!111

James: We are the apostles whom Jesus has chosen!112 We will continue to do and to speak what the Lord has begun!113

Thomas: We are the ones who are sent out! That's what the word apostle means. We have something important, very important, to give to others. ${ }^{114}$

104 John 8:12.

105 John 10:7.

106 John 11:25.

107 John 14:6. Stonehouse (1998:157) postulates that when "those who stand for good win, children are assured that they, too, will have the strength to win over danger and evil".

108 John 15:1.

109 John 1:43. A focus of the play was to honor children and to recognise that the Holy Spirit could also use them for high purposes and noble ends; quite possibly the children could do what the apostles were doing: telling others in the neighbourhood the Good News that Jesus saves (cf. Spurgeon, s.a.:138).

110 Neil, 1973:25.

111 Wall, 2002:38.

112 Matthew 10:1-4.

113 Wall, 2002:37.

114 Wall, 2002:37-38. The idea of Good News means change; the Bible calls it metanoia, conversion (Brown, 1984:157). The Biblical text by nature is con- 
John: We are so enthusiastic about Jesus!115 $\mathrm{He}$ is the Christ!116 God so loved the world that He sacrificed his only son, Jesus. Whoever believes in Jesus will not perish but have eternal life.117

Reporter: You'll probably encounter opposition!118 The Jewish leaders and Roman officials put Jesus to death. You may also be put to death, Thomas.

Thomas: Yes, we expect opposition. But we are told to love those who oppose us and to do good to them.119

(The disciples leave and interact with the audience. Two might be piggybacking. Again, they are having fun and expressing their joy.)

Reporter: Well, thank you, Matthew, Peter, James, John, Andrew, and Thomas. This is SABC EyeWitness News on the Mount of Olives. As you can see, the disciples of Jesus are rejoicing going on their way back to Jerusalem. I'm sure we'll hear more of this good news that Jesus is raised from the dead, is alive, and is seated in heaven.120 They surely will tell others in Jerusalem.121

frontational. The Acts play by its nature challenged its audience by role play to either be a disciple (one charged with telling the Good News of an ascended Jesus) or a hearer like the SABC reporter (one who listened to the disciples' excited story for the first time). It is quite possible that identifying with either role left someone in the audience uncomfortable. But a feeling of being uncomfortable is commonly acknowledged throughout the Biblical text when a message is presented because, again, the Biblical message is confrontational (Brown, 1984:158).

115 A goal of the play was to show disciples - disciples who felt good about themselves, excited about their mission, and loved to be together. The Acts play showed disciples as role models who were excited about their goals in life and loved the Lord Jesus (cf. McNabb \& Mabry, 1990:32).

116 Neil, 1973:25.

117 John 3:16. On earth, Jesus was both God and man in one person, and now as the ascended Lord, He continues to be both God and man in one Person (Needham, 2007:42).

118 Cf. Marshall (1989:29).

119 Matthew 4:43-47.

120 A positive worship experience is to let the text presented produce a result in a congregation's life and in an individual's life (cf. Stevenson-Moessner, 2008:15). 
So Jerusalem: Get ready! This is your SABC EyeWitness News reporter watching as Jesus' jubilant disciples return to Jerusalem. 122

The SABC EyeWitness News reporter summarises for the audience that she and they can expect to hear more from these excited disciples.

121 Marshall, 1989:25. People who commit their lives to child evangelism use a variety of techniques to hold the interest of their young audience. Two such ministers were Willard and Margaret Grant who retired in 1980 after about 35 years of crossing America holding conferences for children. Their conferences, streamlined into 75 minutes a night or day, incorporated visualised singing and visualised Scripture so that the children could remember the words and the Biblical truths; a time of prayer in which the children were encouraged to participate; missionary adventure stories; and marionette dramas. The Grants dressed up in costumes as models of whatever theme they were using nautical, Viking, American West, China (Anderson, 1983:19). The Grants emphasised quality, energy, God's love, costumes for the children, and participation by the children; everything presented was researched (Anderson, 1983:15). Usually their conferences were a week long at a church. The conferences gave the children time to make individual commitments to Christ.

The Acts play incorporated quality and research and was performed as a church worship service and not part of a week-long conference. In looking back, a way the service could have been improved was to engage the audience in more participation. With their "imagination hats" on, I as the SABC reporter could have asked the students to follow the disciples' words and wonder what it was like to see Jesus rise up into the air.

In a venue other than a worship service, a follow-up with the children could incorporate questions like the following (cf. Berryman, 1995:40-41):

- What part of the story did you like best?

- What part of the story do you think is the most important?

- Which character was the most like you?

- How did the story make you feel?

- What did the story make you think about?

- Is there any part of the story we could leave out?

- Does anybody know what happened next in the story?

This kind of "wondering" or imagination requires times and, it is hoped, leads the children more deeply into examining their personal responses (Berryman, 1995:41).

122 Goals of religious education are establishing faith and from that position of faith looking at the text in an informed way (Ratcliff, 1992:133). The Acts play sought to supplement catechism classes the children may already attend (Ratcliff, 1992:136). 
(While there is applause going on, the disciples come back and take their bows with the SABC EyeWitness News reporter.) ${ }^{123}$

\section{List of references}

ALDRICH, J. 1993. Lifestyle evangelism: learning to open your life to those around you. Sisters: Multnomah Books.

ANDERSON, B.W. 2006. The unfolding drama of the Bible. 4th ed. Minneapolis: Fortress.

ANDERSON, M.J. 1983. A miracle ministry to children. Turlock: Kincaid.

BERRYMAN, J.W. 1995. Teaching godly play: the Sunday morning handbook. Nashville: Abingdon.

123 What works in child evangelism? Hunter (1992:91-97) offers the following observations:

- A theology that works remains consistent with the "faith of the fathers" throughout the Bible and history. [The Acts play faithfully presented the Biblical text.]

- The claims of Christianity are not effectively communicated by merely parroting a tradition. These claims must be interpreted meaningfully for an audience, honour its members' culture and life situation, and give the explanation of the gospel in ordinary language. [The play did that.]

- It is necessary to acknowledge that secular people may relate better at first to the humanity of Jesus. [The play mentioned Jesus before his death, after his resurrection, and during his ascension. The play stressed, as the Acts text does, the aliveness of Jesus.]

- Remember that the kingdom of God is a complex subject to modern ears. [The play emphasised that the kingdom of God is a reality, is a mystery, and presents no fear to a believer because God is good and his good purposes will prevail.]

- Remember that every person has a calling. [The play emphasised the upcoming work of the excited disciples: to share the good news of Jesus.]

- In evangelism, present a positive image of Christianity. [The play presented the concept of a loving God who reaches out to the whole world, a world inhabited by sinners.]

Although the play ends quite naturally with bows by the actors, the worship service purposefully added a postscript. Albert Coetzee, one of the actors, stepped forward talked about the meaning of the disciples' excitement. They knew Jesus was alive and wanted above all to tell others. The disciples, and Coetzee himself, had given their lives to Jesus. Coetzee explained in simple language how to do that. In this way, the worship service - which incorporated a welcome, an invitation to put on "imagination hats", an explanation of the book of Acts, a dramatisation of Acts 1:1-12, and an invitation to become an exuberant disciple - involved what Von Balthasar (1990:91) calls "integrated interplay". The audience members were invited to involve themselves with God's ongoing drama. 
BROWN, D. 2008. God and mystery in words: experience through metaphor and drama. Oxford: Oxford University Press.

BROWN, R.M. 1984. Unexpected news: reading the Bible with Third World eyes. Philadelphia: Westminster Press.

CHARLES, G.W. 2008. Rider of the clouds: Psalms 68:1-10, 32-35. Journal for preachers, 31(3):14-16, Easter.

CHILDERS, J. 1998. Performing the Word: preaching as theatre. Nashville: Abingdon.

CLARK, R.E., BRUBAKER, J. \& ZUCK, R.B., eds. 1986. Childhood education in the church. Chicago: Moody.

DARDEN, R. 2006. Reluctant prophets and clueless disciples: introducing the Bible by telling its stories. Nashville: Abingdon.

DIYANNI, R. 2008. Literature: approaches to fiction, poetry, and drama. 2nd ed. Boston: McGraw-Hill.

FRITZ, D.B. 1964. The child and the Christian faith. Richmond: The Covenant Life Curriculum.

FULLER, G.C. 1994. The life of Jesus after the Ascension (Luke 24:50-53; Acts 1:9-11). Westminster theological journal, 56(2):391-398.

GRANT, J. 2007. Christ ascended for us - "I have gone to prepare a place for you." Evangel, 25(2):39-42.

GROSSMAN, L. 2009. Milestones: Frank McCourt. Time, 3, 21 Aug.

HUNTER, G.G., III. 1992. How to reach secular people. Nashville: Abingdon.

KAPIC, K.M. 2005. Receiving Christ's priestly benediction: a Biblical, historical, and theological exploration of Luke 24:50-53. Westminster theological journal, 67(2):247-260.

KAPIC, K.M. \& VANDER LUGT, W. 2007. The Ascension of Jesus and the descent of the Holy Spirit in patristic perspective: a theological reading. Evangelical quarterly, 79(1):23-33.

LONG, T.G. 2001. Beyond the worship wars: building vital and faithful worship: The Alban Institute.

MAILE, J.F. 1986. The Ascension in Luke-Acts. Tyndale bulletin, 37:29-59.

MARSHALL, I.H. 1989. The Acts of the apostles: an introduction and commentary. Grand Rapids: Eerdmans.

MCCORKENDALE, D. 2006. Children's ministry between Easter and Pentecost. Expository times, 117(7):293-294.

MCGOWAN, A. 2007. The ascended Jesus interceding for us. Evangel, 25(2):51-53.

MCNABB, B. \& MABRY, S. 1990. Teaching the Bible creatively: how to awaken your kids to Scripture. Grand Rapids: Zondervan.

MOUNT OF OLIVES. Picture website. www.bibleplaces.com Date of access: 15 May 2010.

NEEDHAM, N. 2007. Christ ascended for us - Jesus' ascended humanity and ours. Evangel, 25(2):42.

NEIL, W. 1973. The Acts of the apostles. London: Oliphants.

NIV Study Bible see STUDY BIBLE, NEW INTERNATIONAL VERSION

O'KEEFE, J.J. \& RENO, R.R. 2005. Sanctified vision: an introduction to early Christian interpretation of the Bible. Baltimore: Johns Hopkins University Press.

QUASH, B. 2005. Theology and the drama of history. Cambridge: Cambridge University Press. 
RATCLIFF, D.E. 1992. Social contexts of children's ministry. (In Ratcliff, D.E., ed. Handbook of children's religious education. Birmingham: Religious Education Press. p. 119-142.)

ROBINSON, E. 1993. The Resurrection and Ascension of our Lord. Bibliotheca sacra, 150(597):9-34.

SHORE, M.H. 2007. Living by the Word. Sunday, May 20, Luke 24:44-53. Christian century, 124(9):21, 1 May.

SPENCE, H.D.M. \& EXCELL, J.S. 1950. The pulpit commentary. Vol. 18: Acts \& Romans. Grand Rapids: Eerdmans.

SPURGEON, C.H.N-D. S.a. "Come ye children": a book on the Christian training of children. Warrenton: Child Evangelism Fellowship.

STEVENSON-MOESSNER, J. 2008. Prelude to practical theology: variations on theory and practice. Nashville: Abingdon.

STONEHOUSE, C. 1998. Joining children on the spiritual journey: nurturing a life of faith. Grand Rapids: Baker.

STUDY BIBLE, NEW INTERNATIONAL VERSION. 1995. Grand Rapids: Zondervan.

VANHOOZER, K.J. 2005. The drama of doctrine: a canonical-linguistic approach to Christian theology. Louisville: John Knox.

VON BALTHASAR, H.U. 1988. Theo-drama: theological dramatic theory. Vol. 1: Prolegomena. Trans. by G. Harrison. San Francisco: Ignatius Press.

VON BALTHASAR, H.U. 1990. Theo-drama: theological dramatic theory. Vol. 2: The dramatis personae: man in God. Trans. by G. Harrison. San Francisco: Ignatius Press.

WALL, R.W. 2002. The Acts of the apostles. (In Keck, L.E., convener. The New Interpreter's Bible: a commentary in twelve volumes. Vol. 10: Acts: Introduction to epistolary literature, Romans, 1 Corinthians. Nashville: Abingdon. p. 1-368.)

WEISSENBUEHLER, W.E. 1992. Acts 1:1-11. Interpretation, 46(1):61-65, Jan.

WHEELER, R. 1997. Creative resources for elementary classrooms and schoolage programs. Albany: Delmar.

WILSON, A. 2007. The Ascension: what is it and why does it matter? Evangel, 25(2):48-51.

Key concepts:

Ascension

child evangelism

Christ, risen

disciples

drama

Holy Spirit

\section{Kernbegrippe:}

Christus, opgestane dissipels

drama

Heilige Gees

Hemelvaart

kinderevangelisasie 